\title{
Review
}

\section{Glycine cleavage system: reaction mechanism, physiological significance, and hyperglycinemia}

\author{
By Goro Kikuchi,${ }^{* 1, \dagger}$ Yutaro Motokawa, ${ }^{* 2}$ Tadashi YoshidA ${ }^{* 3}$ and Koichi HiRAGA ${ }^{* 4}$ \\ (Communicated by Tatsuo SuDA, M.J.A.)
}

\begin{abstract}
The glycine cleavage system catalyzes the following reversible reaction:
Glycine $+\mathrm{H}_{4}$ folate $+\mathrm{NAD}^{+} \rightleftarrows 5,10$-methylene- $\mathrm{H}_{4}$ folate $+\mathrm{CO}_{2}+\mathrm{NH}_{3}+\mathrm{NADH}+\mathrm{H}^{+}$

The glycine cleavage system is widely distributed in animals, plants and bacteria and consists of three intrinsic and one common components: those are i) P-protein, a pyridoxal phosphatecontaining protein, ii) T-protein, a protein required for the tetrahydrofolate-dependent reaction, iii) H-protein, a protein that carries the aminomethyl intermediate and then hydrogen through the prosthetic lipoyl moiety, and iv) L-protein, a common lipoamide dehydrogenase. In animals and plants, the proteins form an enzyme complex loosely associating with the mitochondrial inner membrane. In the enzymatic reaction, H-protein converts P-protein, which is by itself a potential $\alpha$-amino acid decarboxylase, to an active enzyme, and also forms a complex with T-protein. In both glycine cleavage and synthesis, aminomethyl moiety bound to lipoic acid of H-protein represents the intermediate that is degraded to or can be formed from $N^{5}, N^{10}$ methylene- $\mathrm{H}_{4}$ folate and ammonia by the action of T-protein. $N^{5}, N^{10}$-Methylene- $\mathrm{H}_{4}$ folate is used for the biosynthesis of various cellular substances such as purines, thymidylate and methionine that is the major methyl group donor through S-adenosyl-methionine. This accounts for the physiological importance of the glycine cleavage system as the most prominent pathway in serine and glycine catabolism in various vertebrates including humans. Nonketotic hyperglycinemia, a congenital metabolic disorder in human infants, results from defective glycine cleavage activity. The majority of patients with nonketotic hyperglycinemia had lesions in the P-protein gene, whereas some had mutant T-protein genes. The only patient classified into the degenerative type of nonketotic hyperglycinemia had an H-protein devoid of the prosthetic lipoyl residue. The crystallography of normal T-protein as well as biochemical characterization of recombinants of the normal and mutant T-proteins confirmed why the mutant T-proteins had lost enzyme activity. Putative mechanisms of cellular injuries including those in the central nervous system of patients with nonketotic hyperglycinemia are discussed.
\end{abstract}

Keywords: glycine cleavage system, serine and glycine catabolism, crystallography of T-protein, nonketotic hyperglycinemia

*1 Professor Emeritus, Tohoku University, Miyagi, Japan.

$* 2$ Professor Emeritus, University of Tokushima, Tokushima, Japan.

$* 3$ Professor Emeritus, Yamagata University, Yamagata, Japan.

$* 4$ Department of Biochemistry, University of Toyama Graduate School of Medicine and Pharmaceutical Sciences, Toyama, Japan.

$\dagger$ Correspondence should be addressed: G. Kikuchi, 310, 1-18-17 Hayamiya, Nerima-ku, Tokyo 179-0085, Japan (e-mail: g.kikuchi@vanilla.ocn.ne.jp).

\section{Introduction}

Glycine is the simplest amino acid composed of only two carbons and one amino group and can be catabolyzed by way of several metabolic pathways. The major pathway for the catabolism of glycine involves the oxidative cleavage of glycine to $\mathrm{CO}_{2}$, $\mathrm{NH}_{4}{ }^{+}$, and a methylene group $\left(-\mathrm{CH}_{2}-\right)$, which is accepted by tetrahydrofolate $\left(\mathrm{H}_{4}\right.$ folate $)$ in a reversible reaction catalyzed by glycine cleavage system 
(also called glycine synthase) as formulated by ourselves:

$$
\begin{aligned}
& \text { Glycine }+\mathrm{H}_{4} \text { folate }+\mathrm{NAD}^{+} \\
& \rightleftarrows N^{5}, N^{10} \text {-methylene- } \mathrm{H}_{4} \text { folate } \\
& \quad+\mathrm{CO}_{2}+\mathrm{NH}_{4}{ }^{+}+\mathrm{NADH}+\mathrm{H}^{+}
\end{aligned}
$$

The methylene group donated to the coenzyme is used in one-carbon metabolism, and the NADH produced in this process can be used directly to yield energy via the electron-transport system in animals, since the glycine cleavage system is mitochondrial. The glycine cleavage system is present also in various bacteria and plants.

Historically, the glycine cleavage reaction was first described by Sagers and Gunsalus ${ }^{1)}$ in 1961 in cell-free extracts of Diplococcus glycinophilus, an anaerobic bacterium, which fermented glycine to acetate, $\mathrm{CO}_{2}$, and ammonia. Both carbons of acetate were shown to be derived from the $\alpha$-carbon of glycine, while $\mathrm{CO}_{2}$ was from the carboxyl carbon. In 1962 Richert et al. $^{2)}$ described a similar reaction in avian liver preparations. They noticed that a homogenate from pigeon, duck, or chicken liver released a considerable amount of $\mathrm{CO}_{2}$ from the carboxyl group of glycine without forming more than trace of $\mathrm{CO}_{2}$ from the $\alpha$-carbon; most of the $\alpha$-carbon reacted with another molecule of glycine to form serine. Serine hydroxymethyltransferase should be responsible for the serine formation. The data obtained were consistent with the following equation:

$$
\begin{aligned}
& 2 \underset{\times \mathrm{COOH}}{\mid} \mathrm{CH}_{2} \mathrm{NH}_{2}
\end{aligned}
$$

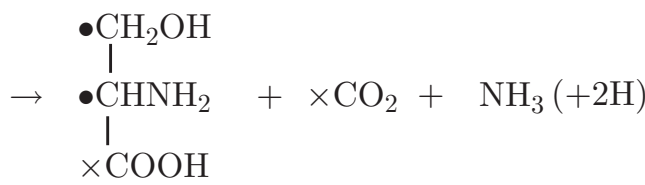

On the other hand, we found in 1966 that rat liver mitochondria catalyzed not only glycine cleavage but also synthesis of two molecules of glycine from one molecule each of serine, bicarbonate, and ammonia. ${ }^{3)}$ Experiments with mitochondrial extracts revealed that in glycine synthesis the $\beta$ carbon of serine and bicarbonate were incorporated specifically into the $\alpha$-carbon and the carboxyl carbon of glycine, respectively, at a stoichiometric ratio of one. ${ }^{4)}$ Ammonia seemed to be the direct and specific amino donor in this reaction. The reaction in vitro required $\mathrm{H}_{4}$ folate and reducing agents such as dithiothreitol or NADH to maintain highly reductive conditions, but did not require the exogenous supply of ATP or GTP. Subsequent studies in vitro in our laboratory established the reversibility of glycine synthesis and glycine cleavage and revealed that the reversible glycine cleavage occurs in all vertebrate livers and other tissues so far tested. ${ }^{5)}$ Moreover, the glycine cleavage reaction has been shown to represent the most significant pathway of not only glycine but also serine catabolism in vertebrates. ${ }^{6), 7)}$

In this review article, we will discuss the results of our experimental findings on the glycine cleavage system of vertebrates and some related subjects in plants, bacteria, and in nonketotic hyperglycinemia patients in infants.

\section{Reaction mechanism}

The glycine cleavage system is composed of four proteins: three enzymes and a carrier protein. ${ }^{8)-10)}$ In animals, the system is loosely bound to the mitochondrial inner membrane. ${ }^{11)}$ The enzymes are i) P-protein (a pyridoxal phosphate-containing protein) or glycine dehydrogenase (decarboxylating) (EC1.4.4.2), ii) T-protein or aminomethyltransferase (EC2.1.2.10), and iii) L-protein or dihydrolipoamide dehydrogenase (EC1.8.1.4). The carrier protein is called H-protein (a lipoic acid-containing protein).

The glycine cleavage reaction catalyzed by the system is partitioned into three partial reactions. The reaction is completely reversible, and in both glycine cleavage and glycine synthesis an aminomethyl moiety bound to the lipoic acid of H-protein represents an intermediate that is subsequently degraded to, or can be formed from, methylene$\mathrm{H}_{4}$ folate and ammonia by the action of T-protein. Possibly the reaction may involve a ternary complex of P-protein, aminomethyl moiety of glycine and H-protein, as a crucial intermediary state. A tentative scheme for the overall reaction of the reversible glycine cleavage is shown in Fig. 1.

1) Reaction catalyzed by $\mathbf{P}$-protein. The first partial reaction of the glycine degradation is the decarboxylation catalyzed by $\mathrm{P}$-protein. Hprotein serves as a co-substrate. One of the most characteristic properties of the glycine cleavage reaction is that, although $\mathrm{P}$-protein should belong 


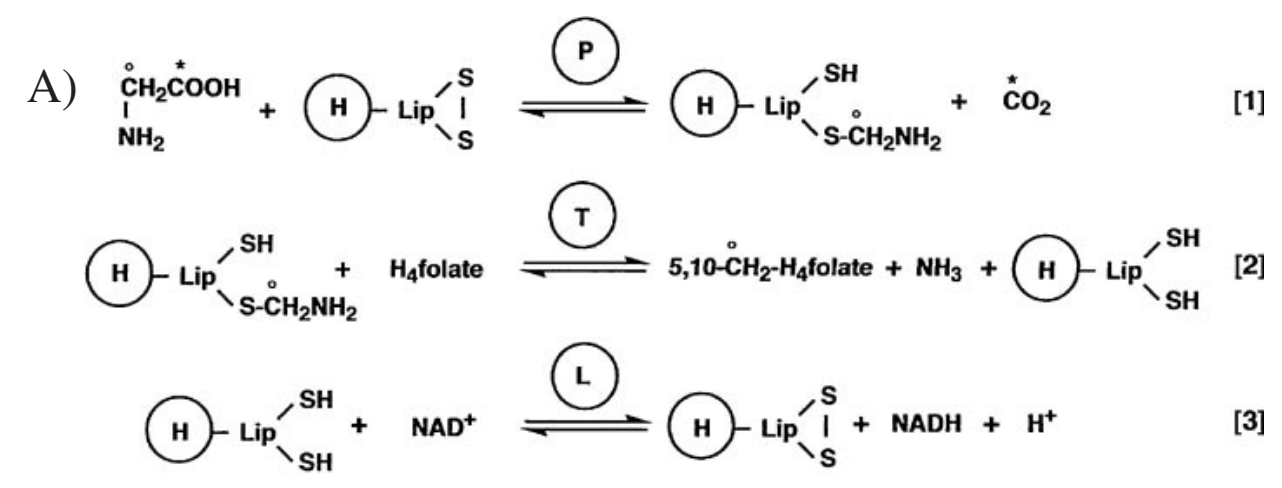

B)

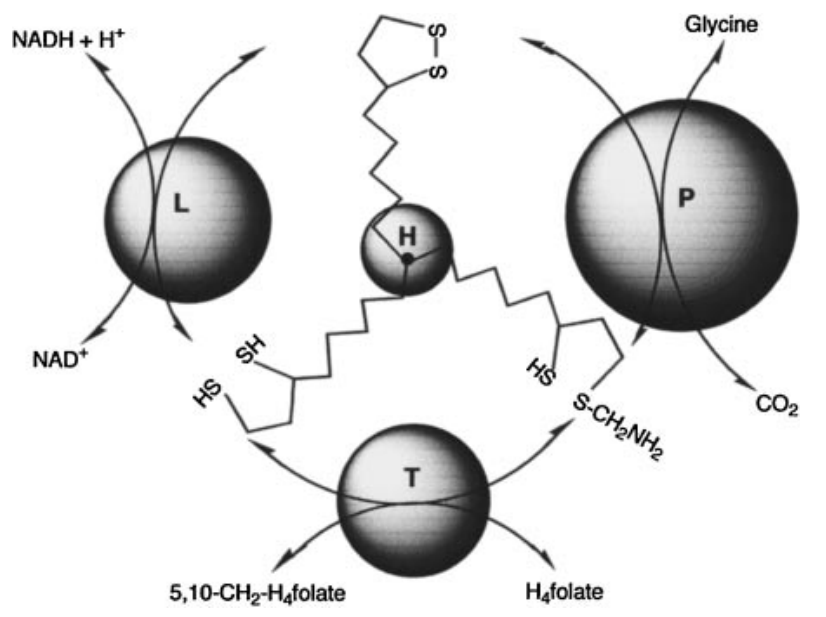

Fig. 1. A) Mechanism of the glycine cleavage reaction. $\mathrm{P}, \mathrm{H}, \mathrm{T}$ and $\mathrm{L}$ in the circles represent respective proteins. Lip, $\mathrm{H}_{4}$ folate, $5,10-\mathrm{CH}_{2}-\mathrm{H}_{4}$ folate represent lipoyl moiety, tetrahydrofolate, and $N^{5}, N^{10}$-methylene- $\mathrm{H}_{4}$ folate, respectively. B) Schematic presentation of the glycine cleavage reaction.

to a class of pyridoxal phosphate-dependent amino acid decarboxylases, P-protein requires H-protein to catalyze the decarboxylation of glycine significantly. The reaction proceeds via a sequential random mechanism where the carboxyl carbon of glycine is converted to carbon dioxide. ${ }^{12)}$ The remnant of the glycine molecule is transferred to one of the sulfhydryl groups formed by the reductive cleavage of disulfide in lipoate attached to $\mathrm{H}$ protein. The H-protein-bound intermediate can be recovered by gel permeation chromatography. ${ }^{13)}$ The attachment of the decarboxylated glycine moiety to lipoate is verified by the appearance of one more sulfhydryl group in H-protein in the course of the reaction ${ }^{13)}$ and confirmed by a crystallographic study employing pea H-protein. ${ }^{14}$ The study revealed that the intermediate is bound to the distal sulfhydryl group.
When glycine, ${ }^{14} \mathrm{CO}_{2}$, and $\mathrm{H}$-protein are present in the reaction mixture, $\mathrm{P}$-protein catalyzes the exchange of the carboxyl group of glycine with ${ }^{14} \mathrm{CO}_{2} \cdot{ }^{13)}$ This reaction is a convenient assay method for P-protein and H-protein.

P-protein, a pyridoxal phosphate-containing protein of about $200 \mathrm{kDa}$, is either a homodimer [e.g., human, ${ }^{15)}$ chicken, ${ }^{15)}$ pea (Pisum sativum), ${ }^{16}$ and Escherichia coli ${ }^{17)}$ or a dimer of heterodimers $\left[(\alpha \beta)_{2}\right.$ ] [e.g., Clostridium acidiurici ${ }^{18)}$ Eubacterium acidaminophilum, ${ }^{19)}$ and Thermus thermophilus $\left.{ }^{20)}\right]$. The former has one molecule of pyridoxal phosphate per subunit, and the latter has one molecule of the cofactor per dimer on the $\beta$ subunit. The pyridoxal cofactor is attached to a specific lysine residue (e.g., Lys-704 of chicken P-protein). ${ }^{21)}$ The heterodimer P-protein of T. thermophilus has an active-site pocket at the interface of the $\alpha$ and $\beta$ 
subunits. ${ }^{20)}$ The pyridoxal cofactor interacts with the active-site pocket noncovalently. The active site of T. thermophilus P-protein is connected to the molecular surface by a channel with a broad entrance facing the solvent. The molecular surface around the channel is composed of several positively-charged amino acid residues, which are possibly involved in the complex formation with $\mathrm{H}$-protein. $^{20)}$

2) Reaction catalyzed by T-protein. The decarboxylated moiety of glycine attached to $\mathrm{H}$ protein is subjected to further degradation catalyzed by $\mathrm{T}$-protein. The reaction requires $\mathrm{H}_{4}$ folate and yields ammonia, $N^{5}, N^{10}$-methylene- $\mathrm{H}_{4}$ folate, and H-protein with reduced lipoate. ${ }^{22}$ In the absence of $\mathrm{H}_{4}$ folate, formaldehyde is produced instead of $N^{5}, N^{10}$-methylene- $\mathrm{H}_{4}$ folate, but the reaction rate is less than $0.05 \%$ of that measured in the presence of $\mathrm{H}_{4}$ folate. ${ }^{22)}$ In the reverse reaction, T-protein catalyzes the formation of the H-proteinbound aminomethyl lipoate intermediate from $N^{5}, N^{10}$-methylene- $\mathrm{H}_{4}$ folate, ammonia, and $\mathrm{H}$-protein with reduced lipoate via an ordered Ter Bi mechanism, in which $\mathrm{H}$-protein is the first substrate to bind followed by $N^{5}, N^{10}$-methylene- $\mathrm{H}_{4}$ folate and ammonia. The order of the product release is $\mathrm{H}_{4}$ folate and the methylamine-loaded H-protein. ${ }^{23)}$

T-protein is a monomer of about $40 \mathrm{kDa}^{17), 24), 25)}$ and forms a 1:1 complex with $\mathrm{H}$-protein. ${ }^{26)} \mathrm{A}$ crosslinking study employing E. coli proteins revealed that the interaction of $\mathrm{H}$-protein with $\mathrm{T}$-protein causes a conformational change of T-protein. Intermolecular contact between Lys-288 of T-protein and Asp-43 of H-protein was found. ${ }^{27)}$ The Nterminal region of $\mathrm{T}$-protein is essential for the interaction with $\mathrm{H}$-protein and for holding $\mathrm{T}$ protein in a compact form. ${ }^{28)}$ The crystal structure of human T-protein has been analyzed in a free form and that bound to $N^{5}$-methyl- $\mathrm{H}_{4}$ folate, an analogue of $N^{5}, N^{10}$-methylene- $\mathrm{H}_{4}$ folate. ${ }^{29)}$ The overall structure consists of three cloverleaf-like structure with the central cavity where the $\mathrm{H}_{4}$ folate cofactor is bound with the pteridin ring deeply buried into the hydrophobic pocket and the glutamyl group pointed to the C-terminal side surface. The structure resembles those of bacterial T-protein from Termotoga naritima, ${ }^{30)}$ E. coli, and Pyrococcus horikoshii OT3. ${ }^{31)}$ Structural and mutational analyses of human T-protein indicated that the invariant Asp-101 might play a key role in the initiation of the catalysis by increasing the nucleophilic character of the $N^{10}$ atom of the folate substrate. ${ }^{29)}$

3) Reaction catalyzed by L-protein. The last step of the glycine cleavage reaction is the reoxidation of the reduced lipoate attached to $\mathrm{H}$ protein catalyzed by L-protein. L-protein is well known as dihydrolipoamide dehydrogenase or E3 protein component of 2-oxoacid (pyruvate, 2-oxoglutarate, and branched-chain 2-oxoacid) dehydrogenase multienzyme complexes. So far no specific L-protein for the glycine cleavage system has been found. In E. coli, the $g c v$ operon which encodes the glycine cleavage system contains no L-protein gene. ${ }^{17)}$

Experiments employing pea L-protein and $\mathrm{H}-$ protein showed that the oxidation of dihydrolipoyl H-protein was not affected by the presence of structurally related analogues such as apoH-protein or octanoylated H-protein. ${ }^{32)}$ The structural interaction between L-protein and $\mathrm{H}$-protein may not be essential for the oxidation reaction.

4) Properties of $\mathbf{H}$-protein. H-protein is a monomeric and heat-stable protein of about $14 \mathrm{kDa} .{ }^{13)}$ Vertebrate H-protein is composed of 125 amino acid residues, and lipoic acid is covalently linked to Lys-59. ${ }^{33)}$ The X-ray crystal structure of the lipoylated pea leaf $\mathrm{H}$-protein (131 residues) revealed that the lipoyl-lysine was localized on the surface of the protein. ${ }^{14)}$ As mentioned above, the lipoyllysine arm on $\mathrm{H}$-protein shuttles the reaction intermediate and reducing equivalents between the active sites of the components of the glycine cleavage system. The mechanism is analogous to that found in 2-oxoacid dehydrogenase complexes. $^{34)}$

Lipoylation of H-protein as well as acyltransferase (E2) components of 2-oxoacid dehydrogenase complexes is catalyzed by lipoate-protein ligase A (LplA) in E. coli. ${ }^{35)}$ The enzyme catalyzes both the formation of lipoyl-AMP from lipoate and ATP and the transfer of the lipoyl-moiety of lipoyl-AMP to H-protein and E2 components. The X-ray crystallographic study showed that LplA consists of a large $\mathrm{N}$-terminal domain and a small $\mathrm{C}$-terminal domain with a substrate-binding pocket at the interface between the two domains. ${ }^{36)}$

In mammals, lipoylation is an intramitocondrial event. Lipoic acid is first activated to lipoylGMP by lipoate activating enzyme, employing GTP as a high-energy compound. ${ }^{37)}$ Lipoate acti- 

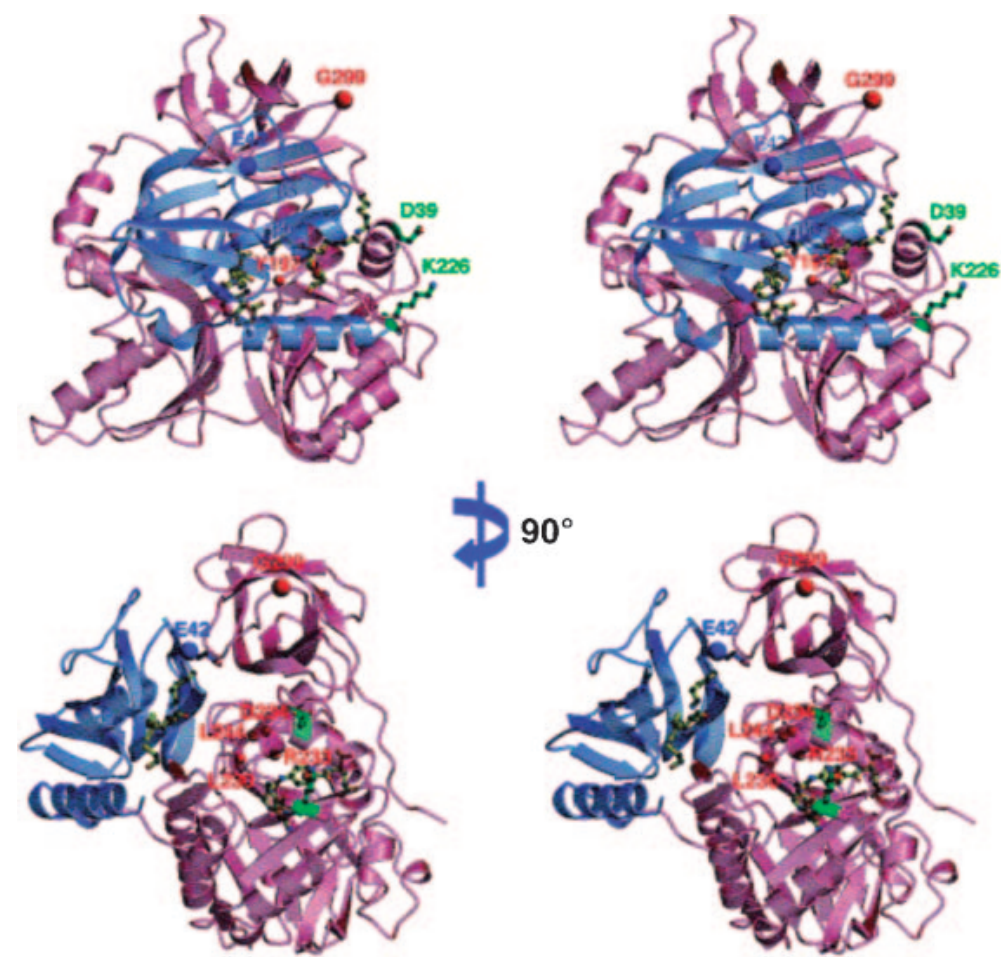

Fig. 2. Stereo ribbon diagrams of the peaH (blue) and humanT (red) complex model. $\mathrm{C}^{\alpha}$ of Gly299 of humanT (red) and Glu42 of peaH (blue) are presented as spheres with labels. The putative residues of humanT interacting with aminomethyl lipoate arm are also presented as spheres with labels (red). The aminomethyl lipoate lysine (Lys63 of peaH) and 5- $\mathrm{CH}_{3}-\mathrm{H}_{4}$ folate are represented in ball-and-stick format with bonds colored in yellow. Asp39 and Lys226 of humanT corresponding to the residues involved in the intramolecular cross-linking in the E.coliT-E.coliH complex are represented in ball-and-stick format with bonds colored and labeled in green. The $\beta$-strands of peaH ( $\beta 5$ and $\beta 6$ ) that form one side of the aminomethyl lipoate-binding cleft are labeled. The lower panel view is obtained by a $90^{\circ}$ rotation of the upper one.

vating enzyme is the same protein already known as xenobiotic-metabolizing medium-chain fatty acid: CoA ligase-III. ${ }^{38)}$ Lipoate is then transferred from lipoyl-GMP to apoproteins by the action of lipoyltransferase. ${ }^{39)}$

5) Enzyme complex nature of the glycine cleavage system. The three-dimensional structure of the complex of the glycine cleavage system has not been elucidated so far. As mentioned above, T-protein forms a complex with H-protein. The crystallization of $\mathrm{T}-\mathrm{H}$ complex has not been reported. A putative complex of T-protein with $\mathrm{H}$ protein was examined graphically using human $\mathrm{T}$ protein and pea H-protein. ${ }^{29)}$ The model was made placing the surface of $\mathrm{H}$-protein embedding the aminomethyl-lipoate into the cavity of T-protein where the $\mathrm{H}_{4}$ folate cofactor is bound. The model did not predict that Glu42 (corresponding to Asp43 of E. coli H-protein) is not in the close vicinity of Gly299 (corresponding to Lys288 of E. coli T- protein). Exact positioning of the two residues may not be prerequisite for complex formation (Fig. 2).

\section{Physiological significance of the glycine cleavage system}

1) Vertebrates. Various pathways have been proposed for the major degradative pathway of glycine as well as serine in vertebrates until early 1960 's. However, now it is widely accepted that the glycine cleavage system is the most prominent pathway in animals. ${ }^{40}$ This view was obtained in 1969 by our study on a case of congenital hyperglycinemia in a human infant. ${ }^{41), 42)}$

a) Catabolism of glycine and serine in the liver of hyperglycinemia patient. Hyperglycinemia is characterized by an extremely high level of glycine in blood and urine, suggesting that hyperglycinemia is associated with a decrease in catabolism of glycine. The hyperglycinemic patient studied was a 15month-old girl at the time of examination, showing 
Table 1. Catabolism of $\left[1-{ }^{14} \mathrm{C}\right]$ glycine and $\left[3-{ }^{14} \mathrm{C}\right]$-DL-serine by liver homogenates from a hyperglycinemic patient and control humans ${ }^{41)}$

\begin{tabular}{|c|c|c|c|c|c|c|}
\hline \multirow[t]{2}{*}{ Source of liver } & \multicolumn{4}{|c|}{$\begin{array}{c}{ }^{14} \mathrm{CO}_{2} \text { formed from }{ }^{14} \mathrm{C} \text {-labeled substrate } \\
\text { listed below }(\mathrm{cpm} / 10 \mathrm{mg} \text { protein } / \mathrm{hr})\end{array}$} & \multicolumn{2}{|c|}{$\begin{array}{l}{ }^{14} \mathrm{C} \text {-Serine formed from } \\
{ }^{14} \mathrm{C} \text {-glycine listed below } \\
(\mathrm{cpm} / 10 \mathrm{mg} \text { protein } / \mathrm{hr})\end{array}$} \\
\hline & $\mathrm{G}-1-{ }^{14} \mathrm{C}$ & $\mathrm{G}-2-{ }^{14} \mathrm{C}$ & $\mathrm{S}-1-{ }^{14} \mathrm{C}$ & $\mathrm{S}-3-{ }^{14} \mathrm{C}$ & $\mathrm{G}-1-{ }^{14} \mathrm{C}$ & $\mathrm{G}-2-{ }^{14} \mathrm{C}$ \\
\hline Patient & 430 & 458 & 1295 & 3180 & 855 & 1060 \\
\hline Control A & 3785 & 358 & 3127 & 861 & 3838 & 8500 \\
\hline Control B & 5683 & 358 & 3330 & 1006 & 5660 & 9410 \\
\hline Control C & 8080 & 520 & 2050 & 1430 & 7240 & 12010 \\
\hline Control D & 5480 & 530 & 1220 & 1849 & 5008 & 8190 \\
\hline Control E & 5050 & 879 & 2100 & 2745 & 4170 & 7155 \\
\hline
\end{tabular}

$\mathrm{G}$ and $\mathrm{S}$ stand for glycine and serine, respectively.

Reaction mixtures contained in a final volume of $2 \mathrm{ml}: 10 \mu$ moles of $\left[1-{ }^{14} \mathrm{C}\right]-$ or $\left[2-{ }^{14} \mathrm{C}\right]$-glycine $(0.05 \mathrm{mCi} / \mathrm{mmole})$ or $20 \mu \mathrm{moles}$ of $\left[1-{ }^{14} \mathrm{C}\right]$ - or $\left[3-{ }^{14} \mathrm{C}\right]$-DL-serine $(0.05 \mathrm{mCi} / \mathrm{mmole})$, and $1 \mathrm{ml}$ of $10 \%$ human liver homogenates containing 12 to $13 \mathrm{mg}$ of protein. Reactions were carried out in Warburg manometric flasks for $1 \mathrm{hr}$ at $37^{\circ} \mathrm{C}$ in air.

general sign of retarded mental and physical development.

In this case, the glycine concentration in the blood was several-fold higher than those of the normal human controls, while other amino acids contents including serine were in the normal ranges. The homogenates from control livers actively catalyzed the decarboxylation of glycine and the decarboxylation was accompanied by the concomitant synthesis of serine (Table 1). With glycine-1${ }^{14} \mathrm{C}\left(\mathrm{HOOC}-\mathrm{CH}_{2}-\mathrm{NH}_{2}\right)$ as substrate, the amount of ${ }^{14} \mathrm{C}$-serine formed was close to the amount of ${ }^{14} \mathrm{CO}_{2}$ formed in respective control specimens. With glycine- $2-{ }^{14} \mathrm{C}$ (HOOC- $\left.\dot{\mathrm{C}} \mathrm{H}_{2}-\mathrm{NH}_{2}\right)$, the yields of ${ }^{14} \mathrm{C}$-serine, in terms of radioactivity, were nearly doubled, while the amounts of ${ }^{14} \mathrm{CO}_{2}$ formed were very small. These results are quite consistent with the equation cited in the Introduction, and indicate that the glycine cleavage system and serine hydroxymethyltransferase function in human liver.

With liver homogenate from the patient, however, the amount of ${ }^{14} \mathrm{CO}_{2}$ from glycine- $1-{ }^{14} \mathrm{C}$ was only a tenth to twentieth of those obtained in the control liver systems. The yields of ${ }^{14} \mathrm{C}$-serine were also very small and were nearly equal with either glycine- $1-{ }^{14} \mathrm{C}$ or glycine- $2-{ }^{14} \mathrm{C}$ as the substrates. These data strongly suggest that the patient is severely deficient (if not absolutely) in the glycine cleavage system. Small amounts of ${ }^{14} \mathrm{CO}_{2}$ derived from glycine- $1-{ }^{14} \mathrm{C}$ or $-2-{ }^{14} \mathrm{C}$ in the reaction with the patient's sample may be due to the activity of alternate pathways of glycine catabolism. The patient was also shown to be normal with respect to serine hydroxymethyltransferase and serine dehydratase, and the serine level in blood was in the normal range.

These facts indicate that the glycine cleavage system plays the critical role in the glycine catabolism under physiological conditions in human.

It is worth-noting in Table 1 that the liver homogenate from the patient significantly catalyzed the ${ }^{14} \mathrm{CO}_{2}$ formation from either of serine- $1-{ }^{14} \mathrm{C}$ and serine- $3-{ }^{14} \mathrm{C}$. Furthermore, the amounts of ${ }^{14} \mathrm{CO}_{2}$ formed from serine- $3-{ }^{14} \mathrm{C}$ was much larger than that from serine- $1-{ }^{14} \mathrm{C}$, while in most of the control system the amounts of ${ }^{14} \mathrm{CO}_{2}$ formed from serine-1${ }^{14} \mathrm{C}$ were larger than or close to those obtained from serine-3- ${ }^{14} \mathrm{C}$. The observed significant ${ }^{14} \mathrm{CO}_{2}$ formation from serine- $3-{ }^{14} \mathrm{C}$ in the patient system could only be accounted for by assuming that considerable portions of serine were cleaved preliminary into glycine and $N^{5}, N^{10}$-methylene$\mathrm{H}_{4}$ folate and the latter was oxidized to $\mathrm{CO}_{2}$, while the glycine formed remained practically unaffected.

The results obtained with ${ }^{14} \mathrm{C}$-labeled serine point to the possibility that the glycine cleavage system would play an important role in the serine catabolism in normal human liver, although serine may also be catabolyzed via pyruvate to some extents.

b) Catabolism of glycine and serine in rat liver. The glycine cleavage system may be the most significant pathway of glycine catabolism in not only man but also other vertebrates, and the major pathway of serine catabolism may be the one which involves the glycine cleavage system in mitochon- 


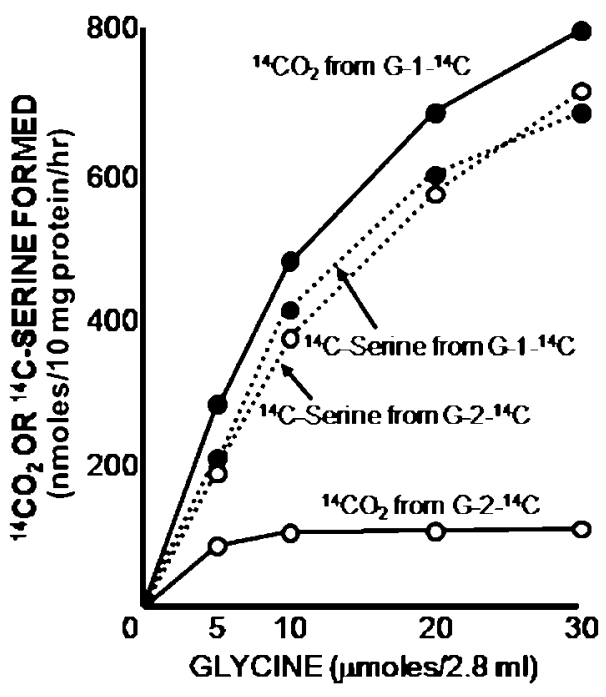

Fig. 3. Glycine metabolism by rat liver mitochondria. ${ }^{43)}$ Reaction mixtures contained, in a final volume of $2.8 \mathrm{ml}$, indicated amounts of ${ }^{14} \mathrm{C}$-glycine $(0.01 \mathrm{mCi} / \mathrm{mmole})$ and $1 \mathrm{ml}$ of mitochondrial suspension containing $10 \mathrm{mg}$ of protein. Reactions were carried out for $60 \mathrm{~min}$ at $37^{\circ} \mathrm{C}$. G stands for glycine.

dria rather than deamination to pyruvate by serine dehydratase in the soluble cell fraction. ${ }^{6), 43), 44)}$

One example is shown in Fig. 3. The rat liver mitochondria catalyzed the decarboxylation of glycine and concomitant synthesis of serine. The observed decarboxylation should be mainly due to the glycine cleavage system, as observed with the human liver. Formation of both ${ }^{14} \mathrm{CO}_{2}$ and ${ }^{14} \mathrm{C}$ serine increased progressively with increased addition of glycine- $1-{ }^{14} \mathrm{C}$. On the other hand, the rate of ${ }^{14} \mathrm{CO}_{2}$ formation from glycine- $2-{ }^{14} \mathrm{C}$ was very low and reached a plateau at a low concentration of the substrate, whereas the yield of ${ }^{14} \mathrm{C}$-serine from glycine-2- ${ }^{14} \mathrm{C}$ increased with increased addition of the substrate. These results clearly show that only small portions of $N^{5}, N^{10}$-methylene- $\mathrm{H}_{4}$ folate which was derived from the $\alpha$-carbon of glycine were oxidized to $\mathrm{CO}_{2}$ and the rest was utilized to synthesize serine with un-reacted glycine by the function of serine hydroxymethyltransferase.

The patterns of glycine catabolism in the homogenate system were essentially similar to those observed in the mitochondrial system, indicating that the catabolism of glycine by the liver homogenate depends essentially on the glycine cleavage system in mitochondria.

Rat liver mitochondria also catalyzed ${ }^{14} \mathrm{CO}_{2}$

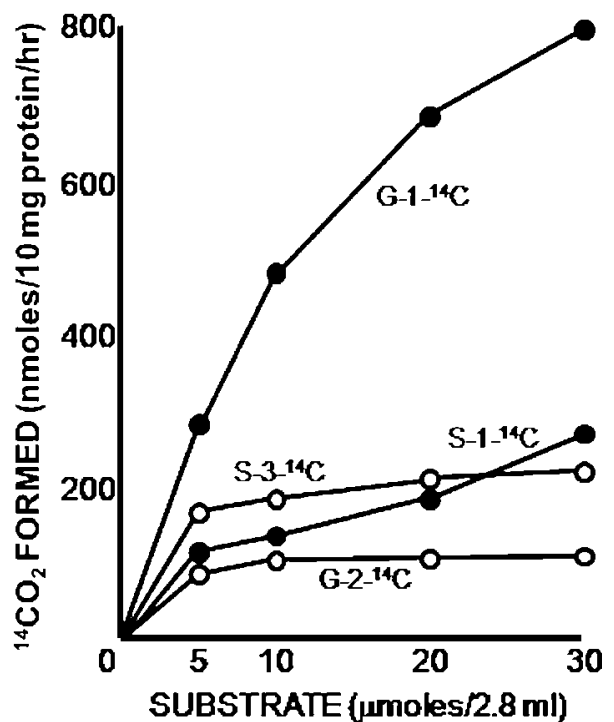

Fig. 4. Comparison of ${ }^{14} \mathrm{CO}_{2}$ formation from ${ }^{14} \mathrm{C}$-serine and ${ }^{14} \mathrm{C}$-glycine catalyzed by rat liver mitochondria. ${ }^{43)}$ Positions of ${ }^{14} \mathrm{C}$ carbon in glycine and serine are shown in the figure. Reaction conditions were similar to those in Fig. 3 except for that various amounts of ${ }^{14} \mathrm{C}$-glycine $(0.01 \mathrm{mCi} / \mathrm{mmole})$ or ${ }^{14} \mathrm{C}$-DL-serine $(0.01 \mathrm{mCi} / \mathrm{mmole})$ were employed. $\mathrm{G}$ and $\mathrm{S}$ stand for glycine and DL-serine, respectively. The amounts of serine in the figure represent the amounts of L-serine.

formation from either serine- $1-{ }^{14} \mathrm{C}$ or serine- $3-{ }^{14} \mathrm{C}$ to some extents (Fig. 4). Since liver mitochondria are devoid of L-serine dehydratase, as is well known, this enzyme obviously does not participate in the observed ${ }^{14} \mathrm{CO}_{2}$ formation form ${ }^{14} \mathrm{C}$-serine. Moreover, when relatively low concentrations of substrates were employed, larger amounts of ${ }^{14} \mathrm{CO}_{2}$ were formed from serine- $3-{ }^{14} \mathrm{C}$ than from serine-1${ }^{14} \mathrm{C}$. Taken together, we conclude that serine was first cleaved into $N^{5}, N^{10}$-methylene- $\mathrm{H}_{4}$ folate and glycine by serine hydroxymethyltransferase, then $N^{5}, N^{10}$-methylene- $\mathrm{H}_{4}$ folate and glycine were oxidized to $\mathrm{CO}_{2}$. Possibly, $N^{5}, N^{10}$-methylene$\mathrm{H}_{4}$ folate was oxidized to $\mathrm{CO}_{2}$ by the sequential action of $N^{5}, N^{10}$-methylene- $\mathrm{H}_{4}$ folate dehydrogenase, cyclohydrolase, and $N^{10}$-formyl- $\mathrm{H}_{4}$ folate: $\mathrm{NADP}^{+}$oxidoreductase. The $N^{5}, N^{10}$-methylene$\mathrm{H}_{4}$ folate formed from the $\beta$-carbon of serine in the soluble fraction may also be oxidized to $\mathrm{CO}_{2}$ via $N^{5}, N^{10}$-methylene- $\mathrm{H}_{4}$ folate and $N^{10}$-formyl- $\mathrm{H}_{4}$ folate without participation of the mitochondria.

c) Catabolism of glycine and serine in livers of various vertebrates. The glycine cleavage system was shown to function in various vertebrates 
including mammals, birds, reptiles, amphibians, and fishes. ${ }^{6}$ ) Intact mitochondria of all vertebrates tested catalyzed ${ }^{14} \mathrm{CO}_{2}$ formation from either glycine- $1-{ }^{14} \mathrm{C}$ or $-2-{ }^{14} \mathrm{C}$, and this was accompanied by concomitant synthesis of ${ }^{14} \mathrm{C}$-serine. The pattern of glycine catabolism was quite the same to those observed for rat liver and human liver. These situations indicate the occurrence of the glycine cleavage system in all the vertebrates tested. Intact liver mitochondria as well as liver homogenates from all the vertebrates tested also catalyzed the ${ }^{14} \mathrm{CO}_{2}$ formation form either serine- $1-{ }^{14} \mathrm{C}$ or $-3-{ }^{14} \mathrm{C}$. In both rat and chicken the glycine cleavage activity was highest in the liver, followed by kidney and brain.

With all vertebrates tested, the activities of serine hydroxymethyltransferase and $N^{5}, N^{10}$ methylene- $\mathrm{H}_{4}$ folate dehydrogenase in the soluble liver fraction were several times higher than those in the mitochondrial fraction on a protein basis. On the other hand, the activity of L-serine dehydratase in the soluble liver fraction was far lower than those of serine hydroxymethyltransferase and other related enzymes in the soluble liver fraction. Taking these observations together, it is quite likely that in all vertebrates, serine is catabolized mainly by way of serine hydroxymethyltransferase rather than serine dehydratase under physiological conditions.

d) Role of the glycine cleavage system in uricotelic animals. During the studies of serine metabolism, we noticed that in uricotelic animals such as chicken and snake, which excrete uric acid instead of urea as the end product of nitrogen metabolism, the activity to form ${ }^{14} \mathrm{CO}_{2}$ from serine- $3-{ }^{14} \mathrm{C}$ was extremely low even after the supplement of $\mathrm{NADP}^{+}$ and $\mathrm{H}_{4}$ folate, while in other ureotelic vertebrates the activity greatly increased on addition of $\mathrm{NADP}^{+}$and $\mathrm{H}_{4}$ folate (Table 2). The observed peculiar situation of the uricotelic animals may be related to the well-known fact that the formation of one molecule of uric acid (a purine compound) requires one molecule of glycine and two molecules of one-carbon compounds together with other essential substrates (cf. Fig. 5). In uricotelic animals, the one carbon compounds formed from glycine or serine may be consumed mostly in uric acid synthesis. In fact, we have observed with chicken that, when ${ }^{14} \mathrm{C}$-serine was used as the source of both glycine and one-carbon compounds,
Table 2. ${ }^{14} \mathrm{CO}_{2}$ formation from DL-serine- $3{ }^{14} \mathrm{C}$ by the liver soluble fraction ${ }^{6)}$

\begin{tabular}{lcc}
\hline \multirow{2}{*}{ Source of liver } & ${ }^{14} \mathrm{CO}_{2}$ formed $(\mathrm{cpm} / 10 \mathrm{mg}$ protein $/ \mathrm{hr})$ \\
\cline { 2 - 3 } & Standard & Plus NADP $^{+}$and THF \\
\hline Human & 203 & 3116 \\
Pig & 248 & 3245 \\
Beef & 476 & 3393 \\
Sheep & 726 & 5310 \\
Dog & 79 & 2910 \\
Rabbit & 899 & 4024 \\
Rat & 82 & 4109 \\
Guinea pig & 307 & 4998 \\
Chicken & 12 & 31 \\
Frog & 155 & 1976 \\
Snake & 23 & 22 \\
Carp & 239 & 3894 \\
\hline
\end{tabular}

Reaction mixtures containing, in a final volume of $2.8 \mathrm{ml}$, $20 \mu$ moles of DL-serine- $3-{ }^{14} \mathrm{C} \quad(0.01 \mathrm{mCi} / \mathrm{mmole}), 1 \mu \mathrm{mole}$ each of $\mathrm{NADPH}$ and $\mathrm{H}_{4}$ folate, and $10 \mathrm{mg}$ of proteins from the liver soluble fraction were incubated for $60 \mathrm{~min}$ at $37^{\circ} \mathrm{C}$.

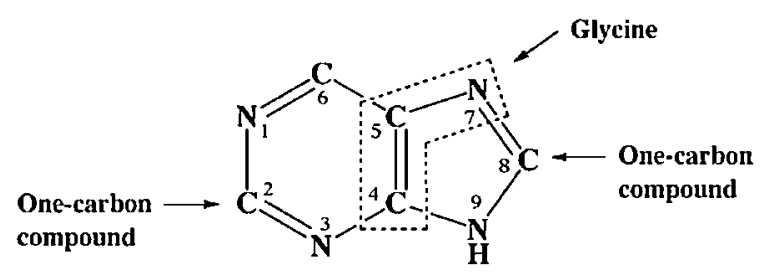

Fig. 5. Chemical structure of purine. Whole structure of glycine provides $\mathrm{C} 4, \mathrm{C} 5$ and $\mathrm{N} 7$ and $N^{10}$-formyl- $\mathrm{H}_{4}$ folate and $N^{5}, N^{10}$-methylene- $\mathrm{H}_{4}$ folate provide $\mathrm{C} 2$ and $\mathrm{C} 8$.

the yield of ${ }^{14} \mathrm{C}$-purine from serine- $3-{ }^{14} \mathrm{C}$ by the soluble liver fractions was approximately twice that obtained from serine- $\left.1-{ }^{14} \mathrm{C} .{ }^{44}\right)$ When the reaction was carried out with a reconstituted homogenate system consisting of mitochondria and the 6-hr dialyzed soluble fraction (to eliminate endogenous one-carbon sources of unknown nature), the ratio of the yields of ${ }^{14} \mathrm{C}$-purine from glycine- $1-{ }^{14} \mathrm{C}$ and -2 ${ }^{14} \mathrm{C}$ rose to $1: 2.3$. This value is close to the theoretically predicted ratio of 1:3 (cf. Fig. 5). These results indicate that in the liver of uricotelic animals such as chicken and snake the glycine cleavage system functions to supply one-carbon compounds for purine synthesis.

e) The major pathway for glycine and serine catabolism in vertebrates. The pathways for glycine and serine catabolism in vertebrate livers under physiological conditions are summarized in 


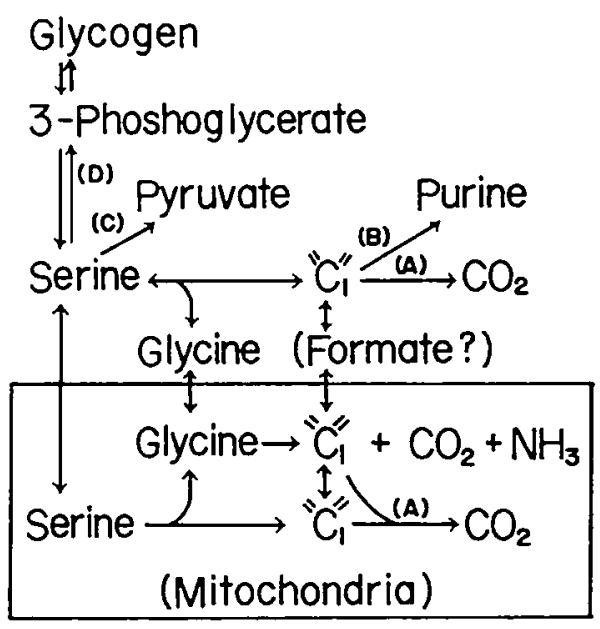

Fig. 6. Pathways for glycine and serine catabolism in vertebrate livers under physiological conditions. Route (A) is considerably limited in uricotelic animals. Route (B) is prevailing in uricotelic animals. Routes (C) and (D) in the soluble fractions are relatively minor. " $\mathrm{C}_{1}$ " denotes $N^{5}, N^{10}$ methylene- $\mathrm{H}_{4}$ folate and other one-carbon compounds.

Fig. 6. ${ }^{6), 40)}$ Glycine catabolism in various vertebrates may principally depend on the glycine cleavage system in mitochondria, although glycine might also be catabolized by way of serine by the sequential reactions of serine hydroxymethyltransferase and serine dehydratase (the route $\mathrm{C}$ in Fig. 6). The latter seems to be meager in the liver soluble fraction, since the distribution of serine dehydratase in various vertebrate organs appears to be severely limited. It is noteworthy in this connection that the patient with congenital hyperglycinemia and therefore with a markedly high level of glycine in blood and urine had normal activities of serine hydroxymethyltransferase and serine dehydratase. $^{42)}$ Probably in all vertebrates, serine catabolism proceeds by way of the cleavage to $N^{5}, N^{10}$-methylene- $\mathrm{H}_{4}$ folate and glycine rather than the serine dehydratase pathway. ${ }^{6), 40)}$ This is particularly pertinent to uricotelic animals, which are devoid of serine dehydratase. ${ }^{44)}$ In rat livers, however, serine dehydratase activity is considerably high and is known to be inducible. Therefore, serine dehydratase may actually catabolize serine to a relatively small extent in rat livers. ${ }^{43}$

f) Plants and bacteria. The glycine cleavage system also occurs and plays an important role in green plants. ${ }^{45), 46)}$ In green leaf cells, the complete process of glycine cleavage occurs in the mitochon- drial matrix via a co-ordinated sequence of reactions. ${ }^{47-49)}$ The glycine cleavage complex from plant leaf mitochondria is similar to the complexes found in the mitochondria of animal tissues and in bacteria such as Peptococcus glycinophilus ${ }^{50)-52)}$ and Arthrobacter globiformis, an aerobic bacterium. ${ }^{53)-55)}$

The $\mathrm{P}, \mathrm{H}$, and $\mathrm{T}$ proteins of the glycine cleavage system were purified separately from pea leaf mitochondria, showing the molecular sizes of $2 \times 97 \mathrm{kDa}, 15.5 \mathrm{kDa}$ and $45 \mathrm{kDa}$, respectively; ${ }^{56), 57)}$ these values are somewhat different from the values in vertebrates cited in Reaction mechanism section.

The glycine cleavage system is present in low amounts in etiolated pea leaves, but increases drastically, up to ten-fold, upon exposure to light. ${ }^{57)}$ In the green leaves the enzymes of the glycine cleavage complex comprise about one-third of the total soluble proteins in the mitochondria. ${ }^{57)}$

The role of glycine cleavage in green leaves is to share a part of "photorespiration". 58),59) In the photosynthesis in chloroplasts, some portion of ribrose-1,5-diphosphate in the Calvin-cycle is oxidatively cleaved to glycolate-2-phosphate and glycerate-3-phosphatae by the oxygenase activity of ribulose 1,5-bisphosphate carboxylase/oxygenase, and glycolate thus formed floods out of the chloroplast and enters the peroxisome and is transformed to glycine via glyoxylate. Then glycine moves to mitochondria and is decomposed to yield $\mathrm{CO}_{2}, \mathrm{NH}_{3}$, NADH and serine by the glycine cleavage system. Serine is then converted mostly to glycerate-3phosphate and re-enters the Calvin cycle.

In other words, the glycine cleavage reaction is a kind of salvage reaction in photosynthesis in green plants. In plant tissues, NADH formed by the glycine cleavage reaction may be utilized mainly for reduction of oxaloacetate to malate rather than for oxidative phosphorylation in the mitochondria. ${ }^{56), 59)}$

Clostridium acidiurici, an anaerobic bacterium, utilizes purine for carbon, nitrogen and energy sources. This purine-fermenting bacterium contains the glycine cleavage system, in other words glycine synthase. ${ }^{18)}$ In this bacterium, this enzyme system is thought to be operative in the direction of glycine synthesis, while synthesis of glycine via glycine synthase in vertebrates is not apparent. ${ }^{40), 60)}$ 


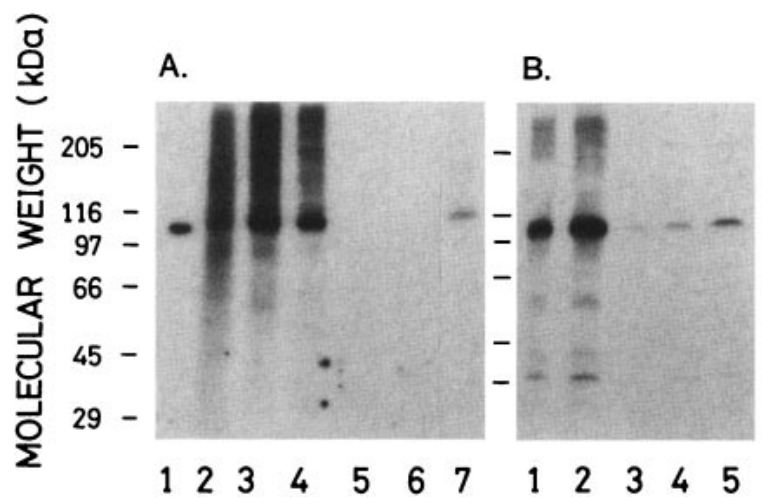

C.

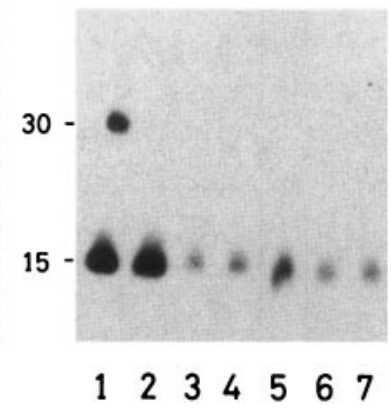

Fig. 7. Immunoblot of P-protein using liver homogenates of patients with nonketotic and ketotic hyperglycinemia. A) Lane 1, purified chicken P-protein (100 ng of protein); lane 2, mitochondrial extract from control human liver (100 $\mu \mathrm{g}$ ); lanes 3 and 4 , control human liver homogenates $(300 \mu \mathrm{g})$; lanes 5 and 6 , liver homogenates from patients with nonketotic hyperglycinemia (neonatal-onset type) $(300 \mu \mathrm{g}$ ); lane 7 , liver homogenate from a patient with propionic academia (one type of ketotic hyperglycinemias) $(300 \mu \mathrm{g})$. B) Lanes 1 and 2, a control liver homogenate (100 and $200 \mu \mathrm{g}$ of proteins); lanes 3 , 4 and 5 , liver homogenates from a patient with a late-onset type of nonketotic hyperglycinemia (50, 100 and $200 \mu \mathrm{g}$ of proteins). Anti-chicken P-protein antibody was used in (A) and (B). C) Immunoblot of H-protein using anti-rat H-protein antibody. Lane 1, purified human H-protein (40 ng); lane 2, human liver mitochondrial extract (100 $\mu \mathrm{g}$ ); lanes 3 and 4, control human liver homogenates; lanes 5, liver homogenate of the patient with propionic academia; lanes 6 and 7, liver homogenates of the patients with neonatalonset type of nonketotic hyperglycinemia. Six $\mu \mathrm{g}$ of proteins were loaded onto lanes 3 to 7 . Note that specimens loaded onto lanes 5,6 and 7 in (A) correspond to those onto lanes 6, 7 and 5 in (C).

\section{Nonketotic hyperglycinemia}

1) General features of nonketotic hyperglycinemia. The glycine cleavage system functions as the major pathway for glycine degradation in vertebrates, so that defective glycine cleavage activity increases glycine concentrations in body fluids. Nonketotic hyperglycinemia is an inborn error of glycine metabolism resulting from defective glycine cleavage activity. Patients under the pathological conditions accompany neurological symptoms such as hypotonia, apnea, and seizures. ${ }^{61)}$ This disease is recognized as neonatal, infatile, and late onset types according to the period of onset of the symptoms. Patients with this disease are mostly lethal at early neonatal periods, except those classified into the late-onset type. $\mathrm{P}-, \mathrm{H}-$, and $\mathrm{T}$ proteins are intrinsic to the glycine cleavage system, while L-protein (lipoamide dehydrogenase) also functions in this system as well as in other metabolic systems such as $\alpha$-keto acid dehydrogenase complexes. Therefore, the genes encoding one of the three intrinsic components may be responsible for nonketotic hyperglycinemia.

2) Molecular lesions of nonketotic hyperglycinemia. Hyperglycinemic conditions in humans were identified as a pathological condition by
Childs et al., ${ }^{62)}$ and Nyhan and collaborators. ${ }^{63), 64)}$ Yoshida et al. identified for the first time that glycine cleavage activity was defective in a patient with hyperglycinemia. ${ }^{41)}$ Subsequently, we purified and characterized chicken P-protein ${ }^{65)}$ as well as H-protein. These progresses enabled us to identify a responsible protein for individual cases of nonketotic hyperglycinemia by enzyme assays using reaction mixtures to which the purified P-protein or H-protein or both had been supplemented. ${ }^{66)}$ Eventually, the leading studies of defective components clarified that nonketotic hyperglycinemia predominantly results from mutations in the $\mathrm{P}$-protein gene. ${ }^{66)}$ Immunoblot using an anti-P-protein antibody revealed that $\mathrm{P}$-protein polypeptide was undetectable in liver specimens from patients with neonatal onset type nonketotic hyperglycinemia (Fig. 7). ${ }^{66}$ Several patients had an affected Tprotein. ${ }^{67)}$ One patient with serious degeneration of the central nervous system ${ }^{68}$ had an inactive H-protein devoid of the prosthetic lipoic acid. ${ }^{69)}$

The characterization of the mutant H-protein was useful to understand properties of glycine decarboxylation by $\mathrm{P}$-protein that requires $\mathrm{H}$ protein for its catalytic activity. Notably, even without the lipoyl moiety, the mutant H-protein could still activate chicken P-protein to a $4 \%$ extent 

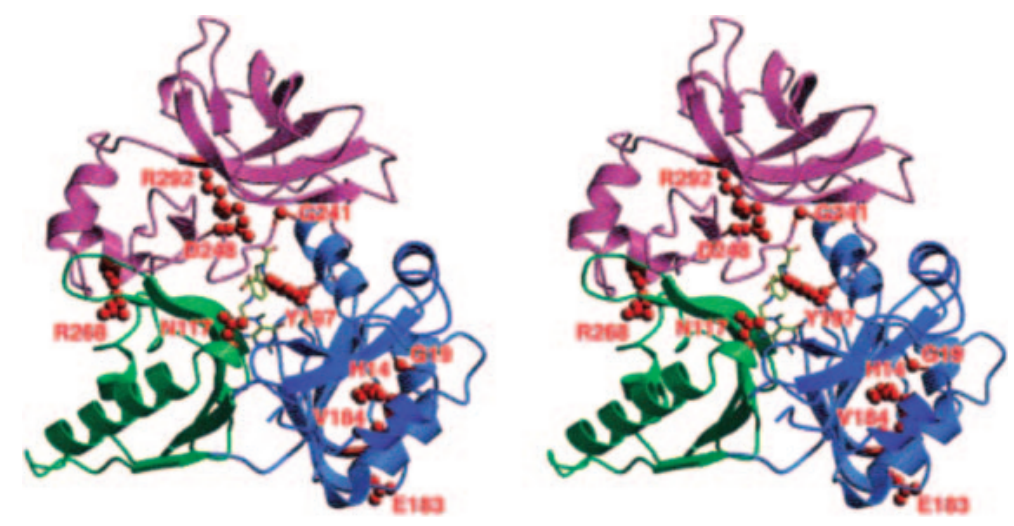

Fig. 8. Nonketotic-hyperglycinemia-related mutation sites mapped on the overall topology of humanT. The mutant residues are depicted in a ball-and-stick representation with atoms colored in red. Residue numbers are labeled.

of the level fully activated by equal amounts of normal human H-protein under comparable assay conditions. ${ }^{69)}$ Moreover, in the absence of glycine, pyridoxal-5'-phosphate on chicken P-protein decreased absorption at $428 \mathrm{~nm}$ in association with both the shift of the maximal absorption to $420 \mathrm{~nm}$ and the increase in absorption at $330 \mathrm{~nm}$ in response to addition of increasing amounts of normal chicken H-protein. ${ }^{65)}$ Thus, the structural change at the active site of P-protein is induced by H-protein. Taking into account the activation of $\mathrm{P}$-protein by the mutant H-protein devoid of the prosthetic lipoic acid, apo-H-protein may be considered to induce the active conformation of $\mathrm{P}$-protein by the interaction of the two proteins. Conclusively, $\mathrm{P}$-protein by itself is an apparently inactive glycine decarboxylase. H-protein may have bipartite functions: those are, 1) the regulatory protein that converts the inactive $\mathrm{P}$-protein to the active glycine decarboxylase and 2) the recipient of the aminomethyl intermediate that is yielded by glycine decarboxylation.

3) Mutation analysis of $\mathbf{P}$-protein genes in patients with nonketotic hyperglycinemia.

Isolation of human cDNA clones each encoding human P-protein (published in terms of glycine decarboxylase cDNA by Hiraga and colleagues), ${ }^{15}$ ) T-protein ${ }^{25)}$ and H-protein ${ }^{70), 71)}$ provided indispensable means to clarify primary structures of the three intrinsic proteins as well as nucleotide sequences of mRNA encoding them. Sakakibara et al. identified $^{73)}$ and Isobe et al. mapped ${ }^{72)}$ that the human genome possesses true and processed Pprotein genes at 9p23-24 and 4q12, respectively.
Sakakibara et al. $^{73)}$ further clarified that a patient with nonketotic hyperglycinemia due to defective activity of $\mathrm{P}$-protein had a mutant $\mathrm{P}$-protein gene that had been deleted at its $5^{\prime}$ region in the genome as the first example of a mutant gene responsible for nonketotic hyperglycinemia. Takayanagi et al. ${ }^{74}$ found similar deletions in familial cases. Deletions of this gene were finally designated as the major cause of this disease. ${ }^{75}$ A cohort analysis using a large number of families of patients with this disease $^{76)}$ also determined various types of basesubstitutions in mutant $\mathrm{P}$ - and T-protein genes.

4) Structure/function relationships of the component proteins. Concerning T-proteins with mutations found in patients with nonketotic hyperglycinemia, Okamura-Ikeda et al. ${ }^{29)}$ mapped nine amino acid residues of the mutations in the hydrogen bonding networks surrounding the substrate binding cavity on the three-dimensional structure of human T-protein together with the enzymological characterization of the recombinant mutants (Fig. 8). The nine residues are His14 (numbering based on mature human T-protein), Gly19, Asn117, Val184, Tyr197, Gly241, Asp248, Arg268 and Arg292. Many of them are involved in hydrogen bonding networks. For example, Asn117 is the central residue of the hydrogen bonding network located in the vicinity of $N^{5} / N^{10}$ groups of bound folate. The network might participate in the positioning of Asp101 and Val115, the putative enhancer of initiation of the $\mathrm{C}_{1}$ unit transfer and the putative selector of reduced folate, respectively. N117I mutant probably causes nonketotic hyperglycinemia due to the dysfunction of these residues (Fig. 8). 
Similarly, the three-dimensional structure of bacterial P-protein has also been predicted. ${ }^{20)}$ Based on presumed similarities in primary structures of the bacterial and human P-proteins, a stereoview of human P-protein has been predicted for the pathogenetic evaluation of mutations found in $\mathrm{P}$-protein genes of patients with nonketotic hyperglycinemia. In this context, the liver specimens from patients with neonatal-onset type of nonketotic hyperglycinemia had no polypeptide reactive to anti-P-protein antibody, whereas a patient with a late-onset type of this disease had a detectable amount of P-protein (Fig. 7). This supports the possibility that the mutant P-proteins of the neonatal onset type are readily degraded in the liver of patients in vivo, even though those are translated to certain extents.

The patients examined had no recognizable mutation in the H-protein gene, except the only patient with serious degeneration in the brain. ${ }^{68), 69)}$ The mutant H-protein of this patient appeared to have no sulfhydryl group of the prosthetic lipoyl residue that is detectable from normal $\mathrm{H}$-protein by $N$-ethylmaleimide under a reduced condition. ${ }^{69)}$ Glycine cleavage activity is predominantly detectable in the liver, kidney, and brain. The heart is a representative tissue inactive in glycine cleavage reaction. This condition solely results from the absence of $\mathrm{P}$-protein, since both $\mathrm{H}$-protein and $\mathrm{T}$ protein were present in the heart at low levels. ${ }^{77)}$ Taking into account that this patient ${ }^{68)}$ was the only case classified into the degenerative type of nonketotic hyperglycinemia, H-protein might have more roles such as those for cell survival.

5) Neuronal dysfunction in patients with nonketotic hyperglycinemia. Nonketotic hyperglycinemia is diagnosed with elevated concentrations of glycine in body fluids and symptoms that represent neuronal dysfunctions. ${ }^{61)}$ Glycine receptors present on inhibitory neurons in the spinal cord may change the motility of skeletal muscles in response to increased concentrations of glycine in body fluids. The NMDA-type glutamate receptor of neurons also has a subunit to which glycine and Dserine can bind to facilitate glutamate-dependent calcium influx through the receptor. ${ }^{78)}$ One can presume that the accumulated glycine causes neuronal death by facilitating the opening of NMDAtype glutamate receptors, followed by excess entry of $\mathrm{Ca}^{2+}$ into the neurons. This might conveniently explain the neuronal death followed by neurological dysfunctions listed above in patients with nonketotic hyperglycinemia. In this context, Furukawa and Gouaux ${ }^{79)}$ demonstrated that glycine and Dserine bind to the glycine site showing $26.4 \mu \mathrm{M}$ and $7.02 \mu \mathrm{M}$ of Ki values, respectively, for the binding of a competitive antagonist, MDL105 519, that shows a $K \mathrm{~d}$ value of $5.86 \mathrm{nM}$. However, the normal value of glycine ( 1 to $2 \mathrm{mM}$ ) in human body fluids is sufficiently high to saturate the binding site for glycine and D-serine on the NMDA-type glutamate receptors. Increasing concentrations of glycine did not cause an enhanced function of this receptor. ${ }^{80}$ ) Therefore, we should more carefully study what causes neuronal death in patients with nonketotic hyperglycinemia.

6) Metabolic incidence of nonketotic hyperglycinemia. Glycine and serine are the major suppliers of active one-carbon derivatives as shown in Fig. 9. Serine hydroxymethyltransferase yields $N^{5}, N^{10}$-methylene- $\mathrm{H}_{4}$ folate and glycine from serine. The product glycine is cleaved to an additional molecule of $N^{5}, N^{10}$-methylene- $\mathrm{H}_{4}$ folate by glycine cleavage reaction. Recent advances of studies related to active one-carbon metabolism have shown that abnormal one-carbon metabolism by mutant $N^{5}, N^{10}$-methylene- $\mathrm{H}_{4}$ folate reductases links to many types of disease; ${ }^{81), 82)}$ collectively, mood disorder, Alzheimer disease, cancers in various tissues, vascular diseases, birth defect, male subfertility, complications during pregnancy, and Down syndrome. In this context, actual one-carbon pool sizes are unclear in patients with nonketotic hyperglycinemia. However, excess glycine in body fluids of the patients with nonketotic hyperglycinemia may conversely reflect the decreased supply of $N^{5}, N^{10}$ methylene- $\mathrm{H}_{4}$ folate. The biosynthesis of TTP and S-adenosylmethionine is likely restricted to a decreased level under which dUTP is incorporated, instead of TTP, into DNA strands during replication. The unmatched bases might be insufficiently repaired under the shortage of TTP, yielding strand breaks at an exceptionally high prevalence. ${ }^{81), 82)}$ Insufficient reparation of the strand breaks leads to apoptotic cell death. Similarly, the shortage of S-adenosylmethionine may alter the statuses of methylation of various cellular substances. ${ }^{81), 82)}$ The abnormal metabolism of the $\mathrm{H}_{4}$ folate derivatives, therefore, accounts for why developing tissues are strongly injured in patients with nonketotic 


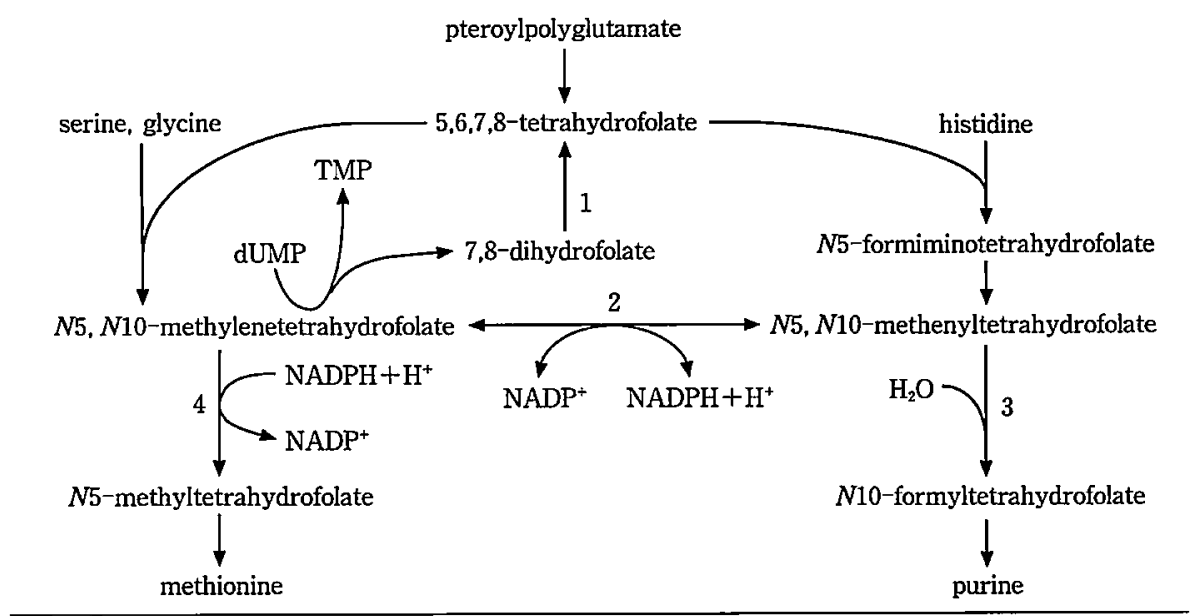

1. dihydrofolate reductase $2, N 5, N 10$-methylenetetrahydrofolate dehydrogenase

3. N5, N10-methenyltetrahydrofolate cyclohydrolase 4 . N5, N10-methylenetetrahydrofolate reductase

Fig. 9. Metabolic map of $\mathrm{H}_{4}$ folate derivatives.

hyperglycinemia. Turning to the neuronal death in the patients, the reduced levels of one-carbon derivatives might be rather appropriate mechanisms underlying cellular injuries including neuronal death in nonketotic hyperglycinemia than the excitotoxic effect of glycine accumulated in body fluids.

\section{Comments}

We have shown that the glycine cleavage system represents the major pathway of glycine and serine catabolism in vertebrates. Molecular basis of the defective glycine cleavage system in nonketotic hyperglycinemia are now well understood. The glycine cleavage system, termed also glycine synthase, is essentially reversible, but catalyzes the glycine synthesis significantly only under anaerobic conditions such as in anaerobic bacteria or anaerobic system in vitro supplemented with $\mathrm{NADH}+\mathrm{H}^{+}$. The glycine synthesis reaction is a highly reductive process, so that under physiological aerobic conditions, glycine may be derived mainly from serine by serine hydroxymethyltransferase rather than de novo synthesis by the back reaction of the glycine cleavage system. It has been shown that the congenital hyperglycinemia patient, who showed markedly high concentrations of glycine in blood and urine, had normal activity of serine hydroxymethyltransferase which catalyzes the cleavage of serine to form glycine and $N^{5}, N^{10}$ methylene- $\mathrm{H}_{4}$ folate. $^{42)}$ The study of glycine syn- thesis reaction, however, was a precious cue that enabled us to profoundly understand physiological and pathological roles of the vertebrate glycine cleavage system. Tada and Kure reviewed pathophysiological studies of this enzyme system. ${ }^{83)}$

In vertebrates, glycine cleavage activity is detectable in the liver, kidney and brain. In those tissues of the chicken, the ratios of specific activities of glycine cleavage reaction and those of levels of polypeptides and mRNA molecules of P-protein and H-protein appeared to be similar (100: 30: 3). ${ }^{77)}$ Moreover, the levels of $\mathrm{P}$-protein and $\mathrm{H}$-protein appeared to be determined at the level of transcription. The heart is a representative tissue inactive in this reaction and had none of mRNA and polypeptide of $\mathrm{P}$-protein, whereas in the heart, $\mathrm{H}$-protein and T-protein were present at low levels. Thus, the presence and absence of $\mathrm{P}$-protein absolutely determine the tissues active and inactive in glycine cleavage reaction. ${ }^{77)}$ The physiological importance of different levels of glycine cleavage activity in the different tissues is unclear at present. In vertebrates, however, transcription regulation of the genes encoding the components is thought to play an important role in determining the physiological basis of glycine metabolism. Properties related to transcription mechanisms of both the P-protein gene and the H-protein gene would provide novel ways to study glycine catabolism intrinsic to different tissues. 


\section{Acknowledgement}

We acknowledge Drs. Hideo Kochi, Kazuko Fujiwara, Kazuko Okamura-Ikeda, Hiroshi Kawaguchi and those who actively collaborated in the work reported here.

\section{References}

1) Sagers, R. D. and Gunsalus, I. C. (1961) Intermediary metabolism of Diplococcus glycinophilus. I. Glycine cleavage and one carbon interconversions. J. Bacteriol. 81, 541-549.

2) Richert, D. A., Amberg, R. and Wilson, M. (1962) Metabolism of glycine by avian liver. J. Biol. Chem. 237, 99-103.

3) Kawasaki, H., Sato, T. and Kikuchi, G. (1966) A new reaction for glycine biosynthesis. Biochem. Biophys. Res. Commun. 23, 227-233.

4) Sato, T., Kochi, H., Motokawa, Y., Kawasaki, H. and Kikuchi, G. (1969) Glycine metabolism by rat liver mitochondria. I. Synthesis of two molecules of glycine from one molecule each of serine, bicarbonate and ammonia. J. Biochem. 65, 63-70.

5) Motokawa, Y. and Kikuchi, G. (1969) Glycine metabolism by rat liver mitochondria. II. Methylene tetrahydrofolate as the direct one carbon donor in the reaction of glycine synthesis. J. Biochem. 65, 71-75.

6) Yoshida, T. and Kikuchi, G. (1972) Comparative studies on major pathways of glycine and serine catabolism in vertebrate livers. J. Biochem. 72, $1503-1516$

7) Yoshida, T. and Kikuchi, G. (1973) Major pathways of glycine and serine catabolism in various organs of the rat and cock. J. Biochem. 73, 10131022.

8) Motokawa, Y. and Kikuchi, G. (1969) Glycine metabolism by rat liver mitochondria. IV. Isolation and characterization of hydrogen carrier protein, an essential factor for glycine metabolism. Arch. Biochem. Biophys. 135, 402-409.

9) Motokawa, Y. and Kikuchi, G. (1974) Glycine metabolism by rat liver mitochondria. Reconstitution of the reversible glycine cleavage system with partially purified protein components. Arch. Biochem. Biophys. 164, 624-633.

10) Motokawa, Y. and Kikuchi, G. (1974) Glycine metabolism by rat liver mitochondria. Isolation and some properties of the protein-bound intermediate of the reversible glycine cleavage reaction. Arch. Biochem. Biophys. 164, 634-640.

11) Motokawa, Y. and Kikuchi, G. (1971) Glycine metabolism in rat liver mitochondria. V. Intramitochondrial localization of the reversible glycine cleavage system and serine hydroxymethyltransferase. Arch. Biochem. Biophys. 146, 461-466.

12) Fujiwara, K. and Motokawa, Y. (1983) Mechanism of the glycine cleavage reaction. Steady state kinetic studies of the P-protein-catalyzed reaction. J. Biol. Chem. 258, 8156-8162.

13) Fujiwara, K., Okamura, K. and Motokawa, Y. (1979) Hydrogen carrier protein from chicken liver. Purification, characterization, and role of its prosthetic group, lipoic acid, in the glycine cleavage reaction. Arch. Biochem. Biophys. 197, 454-462.

14) Pares, S., Cohen-Addad, C., Sieker, L., Neuburger, M. and Douce, R. (1994) X-ray structure determination at $2.6 \AA$ resolution of a lipoate-containing protein. The H-protein of the glycine decraboxylase complex from pea leaves. Proc. Natl. Acad. Sci. USA 91, 4850-4853.

15) Kume, A., Koyata, H., Sakakibara, T., Ishiguro, Y., Kure, S. and Hiraga, K. (1991) The glycine cleavage system. Molecular cloning of the chicken and human glycine decarboxylase cDNAs and some characteristics involved in the deduced protein structures. J. Biol. Chem. 266, 33233329 .

16) Turner, S. R., Ireland, R. and Rawsthorne, S. (1992) Cloning and characterization of the $\mathrm{P}$ subunit of glycine decarboxylase from pea (Pisum sativum). J. Biol. Chem. 267, 5355-5360.

17) Okamura-Ikeda, K., Ohmura, Y., Fujiwara, K. and Motokawa, Y. (1993) Cloning and nucleotide sequence of the gcv operon encoding the Escherichia coli glycine-cleavage system. Eur. J. Biochem. 216, 539-548.

18) Gariboldi, R. T. and Drake, H. L. (1984) Glycine synthase of the purinolytic bacterium Clostridium acidiurici. Purification of the glycine- $\mathrm{CO}_{2}$ exchange system. J. Biol. Chem. 259, 6085-6089.

19) Freudenberg, W. and Andreesen, J. R. (1989) Purification and partial characterization of the glycine decarboxylase multienzyme complex from Eubacterium acidaminophilum. J. Bacteriol. 171, 2209-2215.

20) Nakai, T., Nakagawa, N., Maoka, N., Masui, R., Kuramitsu, S. and Kamiya, N. (2005) Structure of P-protein of the glycine cleavage system: implications for nonketotic hyperglycinemia. EMBO J. 24, 1523-1536.

21) Fujiwara, K., Okamura-Ikeda, K. and Motokawa, Y. (1987) Amino acid sequence of the phosphopyridoxyl peptide from P-protein of the chicken liver glycine cleavage system. Biochem. Biophys. Res. Commun. 149, 621-627.

22) Fujiwara, K., Okamura-Ikeda, K. and Motokawa, Y. (1984) Mechanism of the glycine cleavage reaction. Further characterization of the intermediate attached to $\mathrm{H}$-protein and of the reaction catalyzed by T-protein. J. Biol. Chem. 259, 10664-10668.

23) Okamura-Ikeda, K., Fujiwara, K. and Motokawa, Y. (1987) Mechanism of the glycine cleavage reaction. Properties of the reverse reaction catalyzed by T-protein. J. Biol. Chem. 262, 6746-6749.

24) Okamura-Ikeda, K., Fujiwara, K., Yamamoto, M., Hiraga, K. and Motokawa, Y. (1991) Isolation 
and sequence determination of cDNA encoding T-protein of the glycine cleavage system. J. Biol. Chem. 266, 4917-4921.

25) Hayasaka, K., Nanao, K., Takada, G., OkamuraIkeda, K. and Motokawa, Y. (1993) Isolation and sequence determination of cDNA encoding human T-protein of the glycine cleavage system. Biochem. Biophys. Res. Commun. 192, 766-771.

26) Okamura-Ikeda, K., Fujiwara, K. and Motokawa, Y. (1982) Purification and characterization of chicken liver T-protein, a component of the glycine cleavage system. J. Biol. Chem. 257, 135-139.

27) Okamura-Ikeda, K., Fujiwara, K. and Motokawa, Y. (1999) The amino-terminal region of the Escherichia coli T-protein of the glycine cleavage system is essential for proper association with H-protein. Eur. J. Biochem. 264, 446-452.

28) Okamura-Ikeda, K., Kameoka, N., Fujiwara, K. and Motokawa, Y. (2003) Probing the H-protein induced conformational change and the function of the N-terminal region of Escherichia coli T-protein of the glycine cleavage system by limited proteolysis. J. Biol. Chem. 278, 1006710072.

29) Okamura-Ikeda, K., Hosaka, H., Yoshimura, M., Yamashita, E., Toma, S., Nakagawa, A., Fujiwara, K., Motokawa, Y. and Taniguchi, H. (2005) Crystal structure of human T-protein of glycine cleavage system at $2.0 \AA$ resolution and its implication for understanding non-ketotic hyperglycinemia. J. Mol. Biol. 351, 1146-1159.

30) Lee, H. H., Kim, D. J., Ahn, H. J., Ha, J. Y. and Shu, S. W. (2004) Crystal structure of T-protein of the glycine cleavage system. Cofactor binding, insights into H-protein recognition, and molecular basis for understanding nonketotic hyperglycinemia. J. Biol. Chem. 279, 50514-50523.

31) Lokanath, N. K., Kuroishi, C., Okazaki, N. and Kunishima, N. (2004) Crystal structure of a component of glycine cleavage system. T-protein from Pyrococcus horikoshii OT3 at $1.5 \AA$ resolution. Proteins: Struct. Funct. Genet. 58, 769-773.

32) Neuburger, M., Polidori, A. M., Piètre, E., Faure, M., Jourdain, A., Bourguignon, J., Pucci, B. and Douce, R. (2000) Interaction between the lipoamide containing H-protein and the lipoamide dehydrogenase (L-protein) of the glycine decarboxylase multienzyme system. I. Biochemical studies. Eur. J. Biochem. 267, 2882-2889.

33) Fujiwara, K., Okamura-Ikeda, K. and Motokawa, Y. (1986) Chicken liver H-protein, a component of the glycine cleavage system. Amino acid sequence and identification of the $\mathrm{N}^{\varepsilon}$-lipoyllysine residue. J. Biol. Chem. 261, 8836-8841.

34) Perham, R. N. (2000) Swinging arms and swinging domains in multifunctional enzymes: catalytic machines for multistep reactions. Annu. Rev. Biochem. 69, 961-1004.

35) Green, D. E., Morris, T. W., Green, J., Cronan, J. E. Jr., Guest, J. R. (1995) Purification and properties of the lipoate protein ligase of Escherichia coli. Biochem. J. 309, 853-862.

36) Fujiwara, K., Toma, S., Okamura-Ikeda, K., Motokawa, Y., Nakagawa, A. and Taniguchi, H. (2005) Crystal structure of lipoate-protein ligase A from Escherichia coli: determination of the lipoic acid-binding site. J. Biol. Chem. 280, 33645-33651.

37) Fujiwara, K., Takeuchi, S., Okamura-Ikeda, K. and Motokawa, Y. (2001) Purification, characterization, and cDNA cloning of lipoate-activating enzyme from bovine liver. J. Biol. Chem. 276, 28819-28823.

38) Vessey, D. A., Lau, E. and Kelley, M. (2000) Isolation and sequencing of cDNAs for XL-I and XL-III forms of bovine liver xenobioticmetabolizing medium-chain fatty acid:CoA ligase. J. Biochem. Mol. Toxicol. 14, 11-19.

39) Fujiwara, K., Okamura-Ikeda, K. and Motokawa, Y. (1994) Purification and characterization of lipoyl-AMP: $\mathrm{N}^{\varepsilon}$-lysine lipoyltransferase from bovine liver mitochondria. J. Biol. Chem. 269, 16605-16609.

40) Kikuchi, G. (1973) The glycine cleavage system: composition, reaction mechanism, and physiological significance. Mol. Cell. Biochem. 1, 169-187.

41) Yoshida, T., Kikuchi, G., Tada, K., Narisawa, K. and Arakawa, T. (1969) Physiological significance of glycine cleavagae system in human liver as revealed by the study of a case of hyperglycinemia. Biochem. Biophys. Res. Commun. 35, $577-583$.

42) Tada, K., Narisawa, K., Yoshida, T., Konno, T. Yokoyama, Y., Nakagawa, H., Tannno, K., Mochizuki, K., Arakawa, T., Yoshida, T. and Kikuchi, G. (1969) Hyperglycinemia: A defect in glycine cleavage reaction. Tohoku J. Exp. Med. 98, 289-296.

43) Yoshida, T. and Kikuchi, G. (1970) Major pathway of glycine and serine catabolism in rat liver. Arch. Biochem. Biophys. 139, 380-392.

44) Yoshida, T. and Kikuchi, G. (1971) Significance of the glycine cleavage system in glycine and serine catabolism in avian liver. Arch. Biochem. Biophys. 145, 658-668.

45) Walker, J. L. and Oliver, D. J. (1986) Glycine decarboxylase multienzyme complex. Purification and partial characterization from pea leaf mitochondria. J. Biol. Chem. 261, 2214-2221.

46) Neuburger, M., Bourguignon, J. and Douce, R. (1986) Isolation of a large complex from the marix of pea leaf mitochondria involved in the rapid transformation of glycine into serine. FEBS Lett. 207, 18-22.

47) Oliver, D. J., Neuburger, M., Bourguignon, J. and Douce, R. (1990) Glycine metabolism by plant mitochondria. Physiol. Plant. 80, 487-491.

48) Douce, R., Bourguignon, J., Macherel, D. and Neuburger, M. (1994) The glycine decarboxylase system in higher plant mitochondria: structure, function and biogenesis. Biochem. Soc. Transact. 22, 184-188. 
49) Douce, R., Bourguignon, J., Neuburger, M. and Rebeille, F. (2001) The glycine decarboxylase system: a fascinating complex. TRENDS in Plant Science 6, 167-176.

50) Klein, S. M. and Sagers, R. D. (1966) Glycine metabolism: I. Properties of the system catalyzing the exchange of bicarbonate with the carboxyl group of glycine in Peptococcus glycinophilus. J. Biol. Chem. 241, 197-205.

51) Klein, L. M. and Sagers, R. D. (1966) Glycine metabolism: II. Kinetic and optical studies on the glycine decarboxylase system from Peptococcus glycinophilus. J. Biol. Chem. 241, 206-209.

52) Klein, L. M. and Sagers, R. D. (1967) Glycine metabolism: IV. Effect of borohydride on the pyridoxal phosphate-containing glycine decarboxylase from Peptococcus glycinophilus. J. Biol. Chem. 242, 301-305.

53) Kochi, H. and Kikuchi, G. (1969) Reactions of glycine synthesis and glycine cleavage catalyzed by extracts of Arthrobacter globiformis grown on glycine. Arch. Biochem. Biophys. 132, 359-369.

54) Kochi, H. and Kikuchi, G. (1974) Mechanism of the reversible glycine cleavage reaction in Arthrobacter globiformis. Purification and function of protein components required for the reaction. J. Biochem. 75, 1113-1127.

55) Kochi, H. and Kikuchi, G. (1976) Mechanism of the reversible glycine cleavage reaction in Arthrobacter globiformis. Function of lipoic acid in the cleavage and synthesis of glycine. Arch. Biochem. Biophys. 173, 71-81.

56) Bourguignon, J., Neuburger, M. and Douce, R. (1988) Resolution and characterization of the glycine-cleavage reaction in pea leaf mitochondria. Properties of the forward reaction catalyzed by glycine decaraboxylase and serine hydroxymethyltransferase. Biochem. J. 255, 169-178.

57) Oliver, D. J. Neuburger, M., Bourguignon, J. and Douce, R. (1990) Interaction between the component enzymes of the glycine decarboxylase mutienzyme complex. Plant Physiol. 94, 833839.

58) Artus, N. N., Sommerville, S. C. and Sommerville, C. R. (1968) The biochemistry and cell biology of photorespiration. Crit. Rev. Plant Sci. 4, 121147.

59) Leegood, R. C., Lea, P. J., Adcock, M. D. and Hausler, R. E. (1995) The regulation and control of photorespiration. J. Exp. Botany 46, 13971414.

60) Kikuchi, G. and Hiraga, K. (1982) The mitochondrial glycine cleavage system. Unique features of the glycine decarboxylation. Mol. Cell. Biochem. 45, 137-149.

61) Nyhan, W. L. (1989) In THE METABOLIC BASIS OF INHERITED DISEASE, $6^{\text {th }}$ Ed. (eds. Scriver, C. R., Beaudet, M. D., Sly, W. S. and Valle, D.). McGraw-Hill Information Services Co., NY, pp. $743-753$.

62) Childs, B., Nyhan, W. L., Borden, M., Bard, L. and Cooke, R. E. (1961) Idiopathic hyperglycinemia and hyperglycinuria: a new disorder of amino acid metabolism I. Pediatr. 27, 522-538.

63) Ando, T., Nyhan, W. L., Gerritsen, T., Gong, L., Heiner, D. C. and Bray, P. F. (1968) Metabolism of glycine in the nonketotic form of hyperglycinemia. Pediatr. Res. 2, 254-263.

64) Baumgartner, R., Ando, T. and Nyhan, W. L. (1969) Nonketotic hyperglycinemia. J. Pediatr. 75, 1022-1033

65) Hiraga, K. and Kikuchi, G. (1980) The mitochondrial glycine cleavage system: Purification and properties of glycine decarboxylase from chicken liver. J. Biol. Chem. 255, 11664-11670.

66) Kume, A., Kure, S., Tada, K. and Hiraga, K. (1988) The impaired expression of glycine decarboxylase in patients with hyperglycinemias. Biochem. Biophys. Res. Commun. 154, 292-297.

67) Kure, S., Mandel, H., Rolland, M. O., Sakata, Y., Shinka, T., Drugan, A., Boneh, A., Tada, K., Matsubara, Y. and Narisawa, K. (1998) A missense mutation (His42Arg) in the T-protein gene from a large Israeli-Arab kindred with nonketotic hyperglycinemia. Human Genetics. 102, 430-434.

68) Trauner, D., Page, T., Greco, C., Sweetman, L., Kulovich, S. and Nyhan, W. L. (1981) Progressive neurodegenerative disorder in a patient with nonketotic hyperglycinemia. J. Pediatr. 98, $272-275$.

69) Hiraga, K., Kochi, H., Hayasaka, K., Kikuchi, G. and Nyhan, W. L. (1981) Defective glycine cleavage system in nonketotic hyperglycinemia: Occurrence of a less active glycine decarboxylase and an abnormal aminomethyl carrier protein. J. Clin. Invest. 68, 525-534.

70) Hiraga, K., Kure, S., Yamamoto, M., Ishiguro, Y. and Suzuki, T. (1988) Cloning of cDNA encoding human H-protein, a constituent of the glycine cleavage system. Biochem. Biophys. Res. Commun. 151, 758-762.

71) Koyata, H. and Hiraga, K. (1991) The glycine cleavage system: Structure of a cDNA encoding human H-protein, and partial characterization of its gene in patients with hyperglycinemias. Am. J. Hum. Genet. 48, 351-361.

72) Sakakibara, T., Koyata, H., Ishiguro, Y., Kure, S., Kume, A., Tada, K. and Hiraga, K. (1990) One of the two genomic copies of the glycine decarboxylase cDNA has been deleted at a $5^{\prime}$ region in a patient with nonketotic hyperglycinemia. Biochem. Biophys. Res. Commun. 173, 801-806.

73) Isobe, M., Koyata, H., Sakakibara, T., MomoiIsobe, K. and Hiraga, K. (1994) Assignment of the true and processed genes for human glycine decarboxylase to 9p23-24 and 4q12. Biochem. Biophys. Res. Commun. 203, 1483-1487.

74) Takayanagi, M., Kure, S., Sakata, Y., Kurihara, Y., Ohya, Y., Kajita, M., Tada, K., Matsubara, Y. and Narisawa, K. (2000) Human glycine decarboxylase gene (GLDC) and its highly conserved processed pseudogene (psiGLDC): their structure and expression, and the identification of 
a large deletion in a family with nonketotic hyperglycinemia. Human Genet. 106, 298-305.

75) Kanno, J., Hatchin, T., Kamada, F., Narisawa, A., Aoki, Y., Matsubara, Y. and Kure, S. (2007) Genomic deletion within GLDC is a major cause of non-ketotic hyperglycinemia. J. Med. Genet. 44, e69.

76) Kure, S., Kato, K., Dinopoulos, A., Gail, C., DeGrauw, T. J., Christodoulou, J., Bzduch, V., Kalmanchey, R., Fekete, G., Trojovsky, A., et al. (2006) Comprehensive mutation analysis of GLDC, AMT, and GCSH in nonketotic hyperglycinemia. Hum. Mutat. 27, 343-352.

77) Kure, S., Koyata, H., Kume, A., Ishiguro, Y. and Hiraga, K. (1991) The glycine cleavage system: The coupled expression of the glycine decarboxylase gene and the H-protein gene in the chicken. J. Biol. Chem. 266, 3330-3334.

78) Benveniste, M. and Mayer, M. L. (1991) Kinetic analysis of antagonist action at N-methyl-Daspartatic acid receptors-Two binding sites each for glutamate and glycine. Biophys. J. 59,
$560-573$.

79) Furukawa, H. and Gouaux, E. (2003) Mechanisms of activation, inhibition and specificity: crystal structures of the NMDA receptor NR1 ligandbinding core. EMBO J. 22, 2873-2885.

80) Obrenovitcha, T. P., Hardya, A. M. and Urenjak, J. (1997) High extracellular glycine does not potentiate N-methyl-D-aspartate-evoked depolarization in vivo. Brain Res. 746, 190-194.

81) Lucock, M. and Yates, Z. (2005) Folic acidvitamin and panacea or genetic time bomb? Nat. Rev. Genet. 6, 235-240.

82) Bollheimer, L. C., Buettner, R., Kullmann, A. and Kullmann, F. (2005) Folate and its preventive potential in colorectal carcinogenesis. How strong is the biological and epidemiological evidence? Crit. Rev. Oncol. Hematol. 55, 13-36.

83) Tada, K. and Kure, S. (2005) Nonketotic hyperglycinemia: pathophysiological studies. Proc. Jpn. Acad., Ser. B 81, 411-417.

(Received Feb. 15, 2008; accepted June 13, 2008)

\section{Profile}

Goro Kikuchi was born in 1920. He graduated from Nippon Medical School in Tokyo in 1944 and began research concerned with heme degradation mechanism under Professor Koozoo Kaziro. In 1952, he was appointed to Associate Professor of the Department of Biochemistry. Meanwhile, he engaged research for 2 years with Professor Barron (University of Chicago) and for successive 2 years with Professor Shemin at Columbia University. In the Dr. Shemin's laboratory, he succeeded to demonstrate the enzymatic synthesis of $\delta$-aminolevulinic acid (ALA), the initial intermediate of porphyrin and heme biosynthesis. In 1959, he was invited as Professor of Biochemistry at Tohoku University School of Medicine in Sendai, Japan. In Sendai, his major research subjects were 1) ALA synthase and regulation

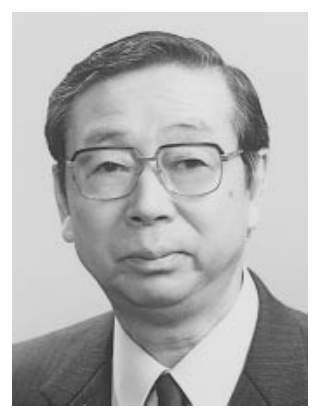
of heme biosynthesis, 2) metabolism of glycine and serine, and 3) heme degradation by heme oxygenase. He was appointed to the President of Nippon Medical School in 1986 and served for the position until 1992, following the retirement from Tohoku University in 1983. He served for the Japanese Biochemical Society (JBS) as the President (1978-1979), the President of the 54 ${ }^{\text {th }}$ Annual Meeting of JBS (1981), and the Managing Editor of the Journal of Biochemistry (1974-1976). He is an honorary member of JBS as well as that of the American Society of Biological Chemists. He received the Promotion of Science Prize from the Naito Memorial Foundation in 1975, Medical Research Prize from the Japan Medical Association in 1981, Medal with Purple Ribbon in 1985 and the Japan Academy Prize in 1993.

\section{Profile}

Yutaro Motokawa was born in 1936. He graduated in 1961 from Tohoku University School of Medicine. He finished the graduate course under Professor Goro Kikuchi in 1966. He worked as Research Associate and Associate Professor in the Department (1966-1977) and received the Promotional Award of JBS for the study on the mechanism of glycine cleavage reaction (1974). He worked as Professor of Institute of Enzyme Research, University of Tokushima from 1977 to the retirement as a Professor Emeritus in 2002. His major research subjects were mechanisms of glycine cleavage reaction and H-protein biosynthesis.

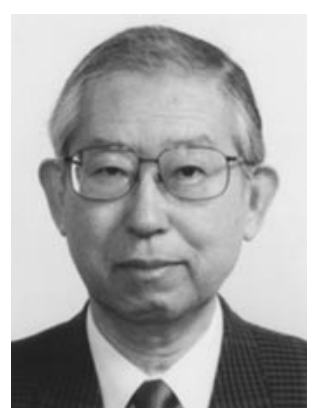




\section{Profile}

Tadashi Yoshida was born in 1941. He graduated from Tohoku University School of Medicine in 1966, finished the Ph.D. course of biochemistry under Professor Goro Kikuchi in 1971. He received the Promotional Award of JBS for the study on heme degradation by the heme oxygenase system in 1979. In 1988, he moved as Professor of Biochemistry to Yamagata University School of Medicine and retired it in 2007 to be a Professor Emeritus. Yoshida's major research subjects were metabolism of glycine and serine, and heme catabolism by heme oxygenase.

\section{Profile}

Koichi Hiraga was born in 1943. He graduated from Tohoku University School of Medicine in 1968, and finished the Ph.D. course under Professor Goro Kikuchi in 1973. He moved as Professor of Biochemistry to Toyama Medical and Pharmaceutical University School of Medicine in 1985. His major research subjects are molecular characterization of both the functions of P-protein and its gene under physiological and pathological conditions, and the roles of galectin-3 in the maintenance of physiological conditions of the liver. 